\title{
Caffeine Protects Against Disruptions of the Blood-Brain Barrier in Animal Models of Alzheimer's and Parkinson's Diseases
}

\author{
Xuesong Chen, Othman Ghribi and Jonathan D. Geiger* \\ Department of Pharmacology, Physiology and Therapeutics, School of Medicine and Health Sciences, University \\ of North Dakota, Grand Forks, ND, USA
}

\begin{abstract}
Sporadic Alzheimer's disease (AD) and Parkinson's disease (PD) are two of the most common neurodegenerative diseases and as such they represent major public health problems. Finding effective treatments for AD and PD represents an unmet and elusive goal largely because these diseases are chronic and progressive, and have a complicated and ill-understood pathogenesis. Although the underlying mechanisms are not fully understood, caffeine, the most commonly ingested psychoactive drug in the world, has been shown in human and animal studies to be protective against AD and PD. One mechanism implicated in the pathogenesis of $\mathrm{AD}$ and $\mathrm{PD}$ is blood-brain barrier $\mathrm{BBB}$ ) dysfunction and we reported recently that caffeine exerts protective effects against $\mathrm{AD}$ and $\mathrm{PD}$ at least in part by keeping the $\mathrm{BBB}$ intact. The present review focuses on the role of $\mathrm{BBB}$ dysfunction in the pathogenesis of $\mathrm{AD}$ and $\mathrm{PD}$, caffeine's protective effects against $\mathrm{AD}$ and $\mathrm{PD}$, and potential mechanisms whereby caffeine protects against BBB leakage.
\end{abstract}

Keywords: Alzheimer's disease, blood-brain barrier, caffeine, Parkinson's disease

\section{THE BLOOD-BRAIN BARRIER AND ITS PATHOPHYSIOLOGICAL IMPORTANCE}

The blood-brain barrier (BBB), an exclusive component of the endothelium of brain capillaries where tight junctions are formed, is an important physical and metabolic barrier that helps keep the central nervous system separate from the systemic circulation [1-3] and that helps regulate and protect the microenvironment of the brain. The protection afforded by the BBB is essential for neuronal survival and proper central nervous

*Correspondence to: Jonathan D. Geiger, Ph.D., Professor and Chair, Department of Pharmacology, Physiology and Therapeutics, University of North Dakota School of Medicine and Health Sciences, 501 N. Columbia Road, Grand Forks, ND 58203, USA. Tel.: +1 701777 2183; Fax: +1 701777 4490; E-mail: jgeiger@medicine. nodak.edu. system functioning [4], and once disrupted, synaptic and neuronal functions can be compromised [5].

The restrictive nature of the $\mathrm{BBB}$ is due mainly to tight junctions formed between adjacent endothelial cells and less so by the presence of an underlying continuous basement membrane [6]. Tight junctions restrict ion flux, paracellular diffusion and infiltration of peripheral inflammatory cells. Tight junctions consist of three transmembrane proteins, occludin, claudins, and junction adhesion molecules (JAM), as well as a number of membrane-associated and accessory proteins including zonula occludens (ZO-1, ZO-2, ZO-3) and cingulin (Fig. 1). One of the first transmembrane tight junction proteins described is occludin, a $65 \mathrm{kDa}$ phosphoprotein [7,8]. Occludin has two extracellular loops, four transmembrane domains and three cytoplasmic domains; the cytoplasmic domain of occludin is directly associated with $\mathrm{ZO}$ proteins. Occludin is highly expressed in brain capillary endothelial cells and 


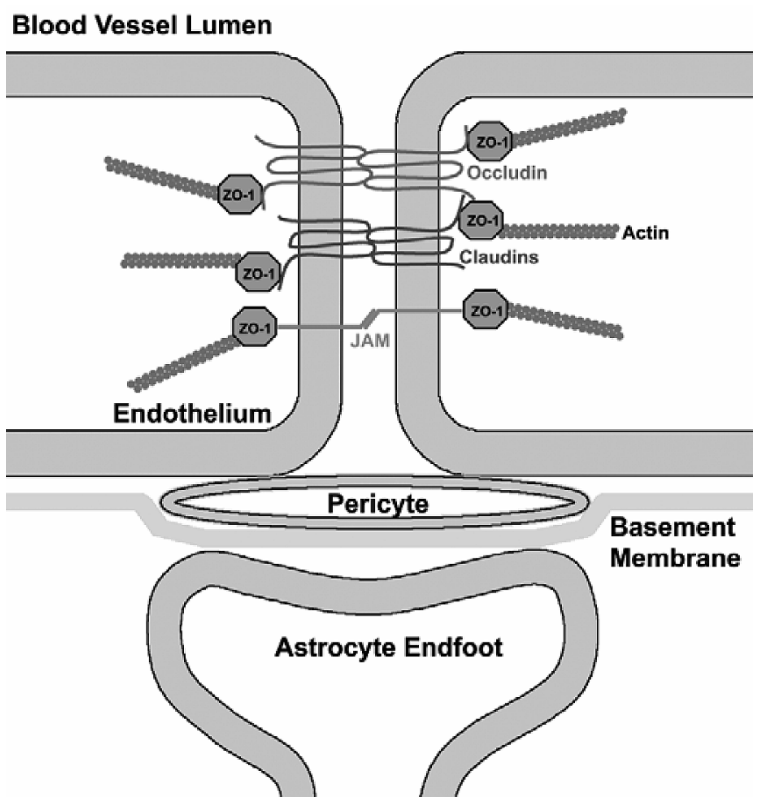

Fig. 1. A schematic diagram of endothelial cells that form the bloodbrain barrier (BBB) and their associations with the lumen of a blood vessel, pericytes, basement membrane and endfeet of astrocytes. The restrictive nature of the $\mathrm{BBB}$ is due to tight junctions between adjacent endothelial cells at the apical membrane and a continuous basement membrane underlying the endothelium. Tight junctions consist of three transmembrane proteins: occludin, claudins, and junction adhesion molecules (JAM), as well as a number of membrane-associated and accessory proteins including zonula occludens (ZO-1).

appears to be a regulatory protein that can alter paracellular permeability [6,9]. Another group of transmembrane tight junction proteins are claudin proteins, $22 \mathrm{kDa}$ phosphoproteins that contain four transmembrane domains. The carboxy terminal of claudin proteins binds to ZO proteins. Claudins form heterodimeric bridges with adjacent cells that block paracellular diffusion [3]. So far, more than 20 isoforms of claudins have been identified in humans and each of them shows a unique pattern of tissue expression [10]; claudin-3 and -5 and possibly -12 are expressed on brain endothelial cells. A third group of transmembrane tight junction proteins are junctional adhesion molecules (JAM) that have a molecular mass of $40 \mathrm{kDa}$ and are separated into three subtypes, JAM-1, JAM-2 and JAM-3. JAM-1 and JAM-3 are expressed in the brain blood vessels [33]. However, the functions of JAM in the BBB are largely unknown.

Membrane-associated guanylate kinase-like proteins and other accessory proteins involved in tight junction formation include $\mathrm{ZO}$ proteins and cingulin [11,12]. Of the three membrane-associated guanylate kinase- like $\mathrm{ZO}$ proteins identified (ZO-1, $\mathrm{ZO}-2$ and $\mathrm{ZO}-3$ ), ZO-1 (220-kDa phosphoprotein), more so than ZO-2 (160-kDa phosphoprotein), links transmembrane tight junction proteins with actin cytoskeleton and stabilizes tight junctions to help maintain BBB integrity [13,14], while ZO-3 is not expressed at the BBB [15]. Other accessory proteins associated with the $\mathrm{BBB}$ include cingulin, AF-6, and 7H6, and they too appear to help regulate interactions between the cytoskeleton, tight junction proteins, and signaling events. It is through linkages between the transmembrane proteins and the actin cytoskeleton that occludin, claudins, and $\mathrm{ZO}$ proteins stabilize BBB tight junctions $[6,16]$.

Tight junctions are dynamic structures that are highly-regulated by tight junction protein expression levels, post-translational modifications, protein-protein interactions, and multiple cell-signaling pathways. Most tight junction proteins are phosphoproteins with multiple sites for phosphorylation, and changes in phosphorylation status of tight junction proteins profoundly affect their respective expression levels, subcellular localization, protein-protein interactions, and the assembly of tight junction proteins at the BBB [1722]. In addition, tight junction proteins are affected by intracellular signaling pathways including levels of intracellular calcium [23-25], vascular endothelial growth factor (VEGF) [26], small G-proteins of the Rho family [21,27-29], and cAMP which stabilizes the BBB [17,30-32]. Increasingly, BBB dysfunction has been implicated in the pathogenesis of a number of acute and chronic neurodegenerative disorders including brain trauma [33], stroke [34], multiple sclerosis [35], HIV-1 dementia [36], Alzheimer's disease (AD) [37], and Parkinson's disease (PD) [38]. Here we will focus on $\mathrm{BBB}$ dysfunction in the pathogenesis of $\mathrm{AD}$ and $\mathrm{PD}$, the two most common neurodegenerative diseases, as well as a pharmacological strategy capable of affecting a wide variety of signaling molecules and stabilizing BBB integrity.

\section{BBB DYSFUNCTION IN AD}

$\mathrm{AD}$, characterized clinically by progressive loss of memory and impaired cognition, is the most common form of irreversible dementia in people over the age of 60 years. Pathologically, AD is characterized by synaptic loss and neuronal cell death, as well as the presence of extracellular amyloid plaques composed of amyloid- $\beta(\mathrm{A} \beta)$ protein and intracellular neurofibrillary tangles composed of phosphorylated tau [39]. A $\beta$ 
is a series of proteolytic by-products of the amyloid- $\beta$ protein precursor $(\mathrm{A} \beta \mathrm{PP})$ that vary in length from 39 to 43 amino acids; $\mathrm{A} \beta$ results from metabolism catalyzed sequentially by $\beta$ - and $\gamma$-secretase enzymes. According to the "amyloid hypothesis", increased levels of $\mathrm{A} \beta$ occur in $\mathrm{AD}$, and $\mathrm{A} \beta$ leads to hyperphosphorylation of tau, synaptic dysfunction, neuronal cell death, and ultimately, impairment of higher cortical activity including memory and cognition. $\mathrm{A} \beta$ (and tau) appear to play a critical role in the pathogenesis of $\mathrm{AD}$, and compelling evidence supports the amyloid hypothesis of early-onset AD [40,41], which is caused by genetic mutations in the $\mathrm{A} \beta \mathrm{PP}$, presenilin- 1 and presenilin-2 genes; all lead to dramatic increases in amyloidogenic processing of $\mathrm{A} \beta \mathrm{PP}$ and $\mathrm{A} \beta$ production. However, early-onset $\mathrm{AD}$ represents less than $5 \%$ of all $\mathrm{AD}$ cases while the vast majority ( $\sim 95 \%$ ) of $\mathrm{AD}$ cases originate sporadically [42]. Although the etiology of sporadic $\mathrm{AD}$ is not known, several risk factors are implicated including the apolipoprotein allele E4 (ApoE4) genotype, previous head injury, and cardiovascular diseases such as atherosclerosis, stroke, and diabetes that could result in cerebrovascular dysfunction.

$\mathrm{BBB}$ dysfunction is implicated in the pathogenesis of $\mathrm{AD}$, and cerebrovascular dysfunction risk factors including atherosclerosis, stroke, and diabetes can lead to BBB dysfunction [43-46]. The first indication of BBB disruption in $\mathrm{AD}$ brain came from the observation that IgG and complement proteins aggregate near plaques, indicating focal or subtle changes in BBB permeability [47]. Subsequent studies confirmed the notion that $\mathrm{BBB}$ disruption is a pathological characteristic of $\mathrm{AD}$ as evidenced by increased leakage of serum proteins into AD brain parenchyma [48-50], increased cerebrospinal fluid (CSF):serum albumin ratios in AD patients [5154], and pathological changes in the microvasculature of $\mathrm{AD}$ brain $[37,55]$. Currently, BBB dysfunction is considered to be one of the earliest pathological events underlying AD [56].

Although the exact mechanisms whereby BBB dysfunction contributes to the pathogenesis of $\mathrm{AD}$ are not fully understood, BBB dysfunction could affect AD pathogenesis by decreasing $\mathrm{A} \beta$ clearance and increasing $\mathrm{A} \beta$ production. Clearance of $\mathrm{A} \beta$ is controlled in part by an intact and functional BBB that transports soluble $\mathrm{A} \beta$ from blood to brain mainly via the Receptor for Advanced Glycation End-products (RAGE), and from brain to blood via the low-density lipoprotein receptor-related protein (LRP-1) [57-59], and depends on the $\mathrm{A} \beta$ chaperone proteins $\mathrm{ApoE}$ and apolipoprotein $\mathrm{J}$ (ApoJ) [60,61]. Thus, altered BBB function could lead to accumulation of $\mathrm{A} \beta$ within brain because of inadequate $\mathrm{A} \beta$ efflux (due to decreased expression of LRP-1), and increased $\mathrm{A} \beta$ influx (due to increased expression of RAGE) [5,59,62-64]. ApoE4 allele, the only known genetic risk factor of sporadic $\mathrm{AD}$, slows $\mathrm{A} \beta$ clearance from brain in an isoform-specific manner [61]. Alternatively, significant amounts of $\mathrm{A} \beta$ are produced in the periphery [65-67]. In addition, $\mathrm{A} \beta$ can be produced locally in and around the $\mathrm{BBB} ; \mathrm{A} \beta \mathrm{PP}$ is expressed in endothelial cells and pericytes, and $\mathrm{A} \beta$ production has been demonstrated in isolated brain microvessels $[68,69]$. Under conditions of increased BBB permeability, which has been shown to occur in $\mathrm{AD}, \mathrm{A} \beta$ from peripheral sources including blood, platelets, and skeletal muscle could flood into brain parenchyma. Increased $\mathrm{A} \beta$ production can also occur as a consequence of BBB disruption and increased entry of blood-borne pathogens, substances, drugs, and peripheral inflammatory cells [70]. Conversely, the presence of $\mathrm{A} \beta$ can adversely affect brain endothelial cells and can disrupt the BBB [71-75]. Therefore, BBB disruption by $\mathrm{A} \beta$ can potentiate further increases in $\mathrm{A} \beta$ accumulation in brain, thus creating a vicious cycle.

\section{THE LINK BETWEEN HIGH LEVELS OF CHOLESTEROL AND DECREASED BBB INTEGRITY IN AD}

One extrinsic factor that contributes to increased $\mathrm{A} \beta$ production and possibly the pathogenesis of sporadic $\mathrm{AD}$ is increased levels of cholesterol; high levels during mid-life increases the risk of developing $\mathrm{AD}$ later in life [76-78]. Under physiological conditions, brain is a net exporter of cholesterol and brain levels of cholesterol are mainly dependent on in situ synthesis and not dietary uptake $[79,80]$. However, under conditions associated with AD pathogenesis the situation may be quite different. For example, with increased BBB leakiness cholesterol in the blood could enter brain and disturb brain cholesterol homeostasis. Furthermore, ApoE4, the major genetic risk factor of sporadic AD, is critical for transportation of cholesterol between cells in brain [81], and is associated with elevated cholesterol levels and an increased risk of developing AD [82-85]. Thus, evidence for an important role of cholesterol in the pathogenesis of AD comes from a variety of experimental approaches including environmental, genetic, and epidemiological.

Experimentally, Sparks and co-workers [86] first reported an association between cholesterol and $\mathrm{A} \beta$ 
production. Subsequently, elevated levels of cholesterol were found to increase A $\beta$ generation [87-89], and lowering cholesterol levels decreased $\mathrm{A} \beta$ production [89-91]. Rabbits fed a diet enriched in cholesterol have for years been used as a model for cardiovascular disorders, especially atherosclerosis. Rabbits fed cholesterol-enriched diets are now known to exhibit neurovascular and other disorders, and we have shown that such diets induce pathological features of AD such as learning deficits, increased $\mathrm{A} \beta$ plaque formation, and hyperphosphorylation of tau [86,92-95]. Moreover, we reported recently that rabbits fed a cholesterolenriched diet exhibit pathological features of $\mathrm{AD}$, including increased BBB leakage and disrupted integrity of the BBB [96]. Thus, elevated levels of cholesterol could contribute to the pathogenesis of $\mathrm{AD}$, at least in part, because the integrity of the $\mathrm{BBB}$ is compromised.

Cholesterol-induced increases in levels of $\mathrm{A} \beta$ in brain might involve increased $\mathrm{A} \beta \mathrm{PP}$ trafficking and increased amyloidogenic processing of $\mathrm{A} \beta \mathrm{PP}$, and increasingly, endosomes/lysosomes have been implicated in amyloidogenesis. An involvement of endocytosis in amyloidogenic processing of $\mathrm{A} \beta \mathrm{PP}$ is suggested by findings of $\mathrm{A} \beta \mathrm{PP}$ and $\mathrm{A} \beta \mathrm{PP}$ cleavage products in clathrin-coated vesicles [97]. The involvement of endosomes/lysosomes was confirmed by findings that $\mathrm{A} \beta$ production was decreased in cultured cells that were stably transfected with an $\mathrm{A} \beta \mathrm{PP}$ construct where the C-terminal endocytic targeting signal was removed [98, 99], and when cells were transfected with a dominantnegative form of dynamin [100]. Furthermore, beta-site amyloid precursor protein-cleaving enzyme-1 (BACE$1)$, the major $\beta$-secretase to cleave the $\mathrm{A} \beta \mathrm{PP}$ to generate $\mathrm{A} \beta$, is localized in endosomes and its activity is optimal under acidic conditions [101-103]. Even more direct evidence for the involvement of endosomes/lysosomes in amyloidosis and AD pathogenesis comes from findings that $\mathrm{A} \beta$ accumulates in neuronal endosomes/lysosomes of AD brain [104], abnormal endosomes occur before extracellular $\mathrm{A} \beta$ is deposited [105], and intraneuronal deposition of $\mathrm{A} \beta$ precedes extracellular deposition of $\mathrm{A} \beta$ [106].

Cholesterol in most types of cells comes largely from lipoproteins up-taken through receptor-mediated endocytosis. Following binding of lipoproteins to its receptors, the receptor-lipoprotein complex is internalized and transported to endosomes/lysosomes where cholesterol esters are hydrolyzed to free cholesterol, which is then transported to various cellular compartments, including plasma membrane and endoplasmic reticulum $[80,107]$. Although brain cholesterol is large- ly derived from de novo synthesis within the brain, lipoprotein transport across the BBB can play a role in delivering essential lipids including cholesterol to brain cells $[108,109]$. In brain, ApoE is the major endogenous lipoprotein that transports cholesterol from astrocytes to neurons, and neurons express low density lipoprotein (LDL) receptors, including low density lipoprotein receptors (LDLR), very low density lipoprotein receptors(VLDLR), and LRP-1 [110-112]. It has been shown that receptor-mediated endocytosis of cholesterol promotes $\mathrm{A} \beta \mathrm{PP}$ internalization and processing [81,113-118]. Under conditions when circulating LDL cholesterol levels are high, high levels of LDL cholesterol would be expected to enhance receptormediated endocytosis of cholesterol at the BBB and thereby impair endothelial barrier function $[119,120]$. Alternatively, high levels of LDL cholesterol could promote amyloidogenic processing of $\mathrm{A} \beta \mathrm{PP}$, increase $\mathrm{A} \beta$ production, and in so doing impair the $\mathrm{BBB}$ function. Once the BBB is disrupted, it is expected that increased levels of LDL cholesterol coming from the periphery could increase brain levels of cholesterol, enhance neuronal uptake of cholesterol, and increase $\mathrm{A} \beta \mathrm{PP}$ trafficking, amyloidogenic processing of $\mathrm{A} \beta \mathrm{PP}$, and $\mathrm{A} \beta$ generation.

\section{BBB DYSFUNCTION IN PD}

PD is a chronic neurodegenerative disease characterized clinically by tremor, bradykinesia, rigidity, and postural instability, and pathologically by loss of dopaminergic neurons mainly in the substantia nigra pars compacta [38]. Although the etiology of PD is not known, the observation that the neurotoxin 1-methyl4-phenyl-1,2,3,6-tetrahydropyridine (MPTP) causes a parkinsonian syndrome similar to PD has led to the hypothesis that environmental toxins similar to MPTP could play an important role in the pathogenesis of PD [121]. The cellular and molecular mechanisms underlying the pathogenesis of PD are unclear at present, but PD has been linked increasingly to neuroinflammation and oxidative stress [122-125].

Similar to AD, BBB dysruption may play an important role in the pathogenesis of PD. Increasingly, BBB dysfunction has been reported to contribute to PD progression [38,126,127], and it has been found that pesticides disrupt BBB permeability [128], that neuroinflammation and oxidative stress compromises BBB [129-133], that pathological alterations in endothelial cells within the substantial nigra are noted in 
patients with PD [134] and BBB dysfunction is present in PD patients [38], that BBB disruption occurs in PD animal models including MPTP-treated mice [133] and 6-hydroxydopamine (6-OHDA)-treated rats [135], and that $\mathrm{BBB}$ disruption precedes dopaminergic neuronal loss in substantial nigra [136]. Thus, BBB dysfunction appears to contribute, at least in part, to the pathogenesis of PD and may help explain why even short exposures to MPTP could result in the development of a progressive parkinsonian disorder.

\section{CAFFEINE AND ITS MECHANISM(S) OF ACTIONS}

Caffeine, the main topic of these reviews, is widely consumed $[137,138]$ and has diverse pharmacological actions [138]. Of relevance to the control of BBB integrity, caffeine's actions have been shown to be mediated through blocking cell surface adenosine receptors, through inhibition of cAMP phosphodiesterase (PDE) activity, and by affecting the release of calcium from intracellular stores. Each of these three mechanisms has been implicated in modulating BBB functions, and the effects of caffeine on these mechanisms are clearly concentration- and dose-dependent.

Caffeine at low concentrations ( $\mu \mathrm{M}$ range) can block all four subtypes of adenosine receptors $\left(\mathrm{A}_{1}, \mathrm{~A}_{2 A}\right.$, $\mathrm{A}_{2 B}$ and $\mathrm{A}_{3}$ ), with most of its actions being mediated through inhibition of the high-affinity $\mathrm{A}_{1}$ and $\mathrm{A}_{2 A}$ receptors and, to a lesser extent, the low-affinity $\mathrm{A}_{2 B}$ and the high-affinity low-density $\mathrm{A}_{3}$ receptors [137]. These receptors are $G$ protein-coupled receptors that affect many cell-signaling mechanisms including cAMP. Activation of $A_{1}$ and $A_{3}$ receptors leads to the inhibition of adenylate cyclase by $\mathrm{G}_{i}$ and decreases intracellular levels of cAMP, whereas activation of $\mathrm{A}_{2 A}$ and $\mathrm{A}_{2 B}$ receptors stimulates adenylate cyclase through $\mathrm{G}_{s}$ and increases intracellular levels of cAMP [139]. Because caffeine is commonly ingested chronically, it is important to note that long-term exposure to adenosine receptor antagonists like caffeine can have effects that resemble the acute effects of adenosine receptor agonists [140], due likely to up-regulation of adenosine receptors $\left(\mathrm{A}_{1}\right.$ and $\left.\mathrm{A}_{2 A}\right)$ and adaptive changes leading to adenosine receptor sensitization [140-142]. At higher concentrations, caffeine and its intermediate metabolites such as theophylline, theobromine, and paraxanthine can elevate intracellular cAMP levels by inhibiting cAMP PDE activity [137]. At high, possibly toxic concentrations ( $\mathrm{mM}$ range), caffeine can mobilize cal- cium from endoplasmic reticulum stores through actions of $\mathrm{IP}_{3}$ and ryanodine receptors $[137,143]$. Caffeine is also known to affect a number of other cell signaling molecules and physiological functions, the composite of which may affect the pathogenesis of AD and PD as well as BBB structure and function.

\section{THE ROLE OF THE BBB IN THE PROTECTIVE EFFECTS OF CAFFEINE IN ANIMAL MODELS OF AD AND PD}

Recent epidemiological and experimental studies indicate that caffeine, when administered chronically, has beneficial effects against a number of acute and chronic neurological disorders including stroke, AD, and PD [144-156]. For AD, the protective effects of caffeine have been observed in humans as well as in animal models of this neurodegenerative disorder. Epidemiologically, chronic ingestion of caffeine conferred protective effects against AD $[157,158]$, and a retrospective study showed that caffeine intake is associated with a significantly lower risk for AD [150]. Prospective studies confirmed the above findings by showing that chronic caffeine intake improved memory and cognitive function in normal aged individuals as well as in AD patients [148,151,159-162]. Subsequently, experimental studies conducted using animal models of AD noted that caffeine improved cognitive abilities [149, $163]$, reduced $\mathrm{A} \beta$ production [149,163,164], and stabilized BBB integrity [96]. Thus, caffeine and drugs like caffeine might be part of any regimen intended to prevent, delay, and/or treat AD.

For PD, it was reported some 35 years ago that caffeine through blocking adenosine receptor activation could ameliorate parkinsonian symptoms [165]. Subsequent retrospective, prospective, and epidemiologic studies demonstrated that caffeine, when administered chronically, decreased the risk of developing PD [152155]. Experimental studies confirmed and extended the epidemiological findings by showing that caffeine was neuroprotective against the loss of dopaminergic neurons that occurs in the substantial nigra of MPTPtreated mice [166]. Thus, current evidence strongly suggests that caffeine is a promising agent in the prevention and/or treatment of PD [167]. Although the mechanisms whereby caffeine exerts its protective effects on PD are not fully understood, much work has been conducted on the involvement of adenosine receptors in the pathogenesis and possible treatment of PD [168]. Of the identified adenosine receptor 
subtypes, the main focus continues to be on $\mathrm{A}_{2 A}$ receptors [169], and preclinical studies suggest strongly that $\mathrm{A}_{2 A}$ receptor antagonists are protective against PD [170-174]. However, clinical trials with an $\mathrm{A}_{2 A}$ receptor antagonist were rather disappointing in that only minimal improvements in PD symptomatology were noted in the PD patients $[175,176]$. Nevertheless, $\mathrm{A}_{2 \mathrm{~A}}$ receptor antagonists may still prove to be effective against PD, because those clinical trials were designed to determine only the extent to which they might show a therapeutic effect in patients already living with PD. Results from animal studies and epidemiological studies have demonstrated repeatedly that caffeine and blockade of adenosine $\mathrm{A}_{2 A}$ receptors afford prophylactic protection and not therapeutic rescue of endpoints related to PD. Furthermore, it remains a possibility that an inadequate dose of the $\mathrm{A}_{2 A}$ receptor antagonist was tested in the clinical trials.

BBB dysfunction has been implicated in the pathogenesis of $\mathrm{AD}$ [48-50], and although more controversial, PD as well $[38,126,127]$. Thus, caffeine might exert its protective effect against $\mathrm{AD}$ and $\mathrm{PD}$ by virtue of its action on the BBB. Indeed, we reported recently that chronic ingestion of caffeine protected against BBB dysfunction in both a rabbit model of sporadic AD [96] and a mouse model of PD [177]. In a rabbit model of sporadic AD, we demonstrated that caffeine ( $3 \mathrm{mg} /$ day, a human equivalent of $\sim 1$ cup of coffee per day) blocked cholesterol-enriched diet-induced increases in leakage of Evan's blue dye (Fig. 2A), and decreases in levels of the tight junction proteins occludin (Fig. 2B, C) and ZO-1. In a MPTP neurotoxin model of PD, we demonstrated that caffeine $(10 \mathrm{mg} / \mathrm{kg}$, a human equivalent of $\sim 5$ cup of coffee per day) blocked MPTP-induced increases in leakage of Evan's blue dye (Fig. 2D), and decreases in levels of the tight junction proteins occludin (Fig. 2E, F) and ZO-1 specifically in striatum. Although the molecular mechanisms by which caffeine protects against BBB dysfunction remain unclear, the mechanisms to consider include blockade of adenosine receptors, inhibition of cAMP PDE activity, or mobilization of intracellular calcium from endoplasmic reticulum stores. Because the doses needed to stabilize the BBB in animal models of AD and $\mathrm{PD}$ were in the pharmacologically relevant range, the protective effects of caffeine on the BBB are most likely achieved through blockade of adenosine receptors. Of the four subtypes of adenosine receptors, $\mathrm{A}_{2 A}$ and $A_{2 B}$ receptors are most prominently expressed on brain endothelial cells $[178,179]$, and their activation elevates intracellular levels of cAMP, which is well known to stabilize the BBB [17,30-32]. That this is an underlying mechanism for the action of caffeine is supported more directly by findings that activation of $\mathrm{A}_{2 B}$ receptors protects against vascular leakage [180]. However, to invoke such a mechanism it is important to note that, although the direct effect of acutely administered caffeine blocks adenosine receptors $\left(\mathrm{A}_{2 A}\right.$ and $A_{2 B}$ ), thus decreasing intracellular levels of cAMP, chronic ingestion of caffeine as occurs typically in humans can result in up-regulation of adenosine receptors $\left(\mathrm{A}_{2 A}\right.$ and $\left.\mathrm{A}_{2 B}\right)$ on brain endothelial cells and/or increased sensitivity of adenosine receptors $\left(\mathrm{A}_{2 A}\right.$ and $\mathrm{A}_{2 B}$ ) to their endogenous ligand, adenosine. Thus, under conditions when and where brain levels of adenosine are high [181-184], the activation of already sensitized and/or up-regulated adenosine receptors on brain endothelial cells, especially during the discontinuous presence of caffeine, could lead to greater elevation of intracellular levels of cAMP, thus protecting the $\mathrm{BBB}$ against disruption. Our observation that caffeine specifically affects the striatum in the MPTP neurotoxin model of PD could be related to the very high density of adenosine $\mathrm{A}_{2 A}$ receptors found normally in that brain region $[137,166]$. It is also possible that caffeine could stabilize the BBB by increasing intracellular levels of cAMP via inhibition of cAMP PDE activity in brain endothelial cells $[137,185]$, but this is not so likely because cAMP PDE has an approximately 1-2 order of magnitude less sensitivity to caffeine compared to adenosine $A_{1}, A_{2 A}$, and $A_{2 B}$ (but not $A_{3}$ ) receptors. In addition, the observed protective effects of caffeine on endothelial cells of the BBB in our animal models, especially the rabbit $\mathrm{AD}$ model, might have been due to changes in lipids and/or cholesterol metabolism [186$188]$, inhibiting endocytosis [189,190], and/or affecting lysosomal $\mathrm{pH}$ and trafficking [191,192].

In addition to its actions on endothelial cells, caffeine might exert its protective effects on the BBB indirectly through modulation of other cell types in brain including astrocytes, microglia, and neurons. Activation of astrocytes and microglia are major components of neuroinflammation, which is implicated in the pathogenesis of both AD and PD [193,194]. Reactive gliosis can release a cascade of proinflammatory and neurotoxic factors including TNF- $\alpha$, IL-1 and reactive oxygen species [193,195-198], all of which can disrupt the BBB [24]. The leaky BBB could further potentiate neuroinflammatory responses by allowing peripheral inflammatory cells to infiltrate into brain parenchyma, creating a vicious cycle. Several lines of evidence indicate that caffeine and the adenosine receptors it is 
A

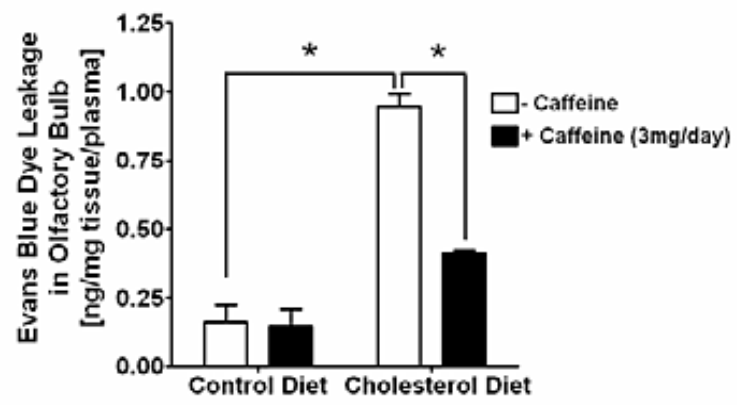

B

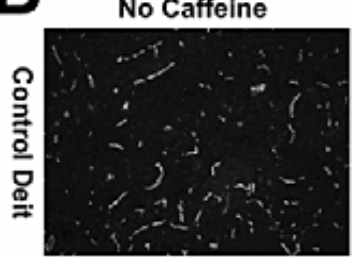

Caffeine (3 mg/day)
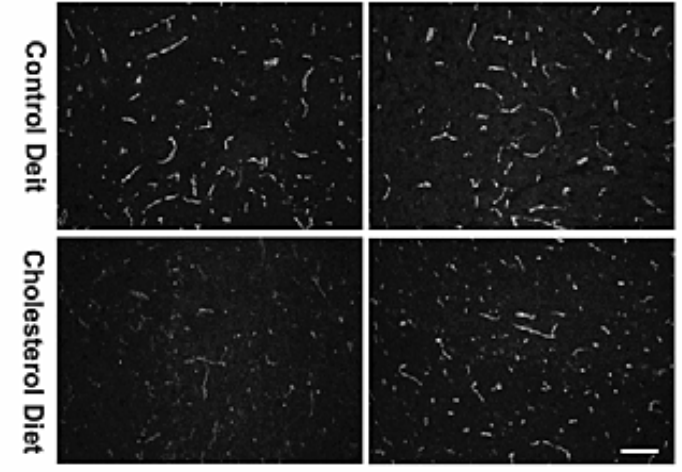

C

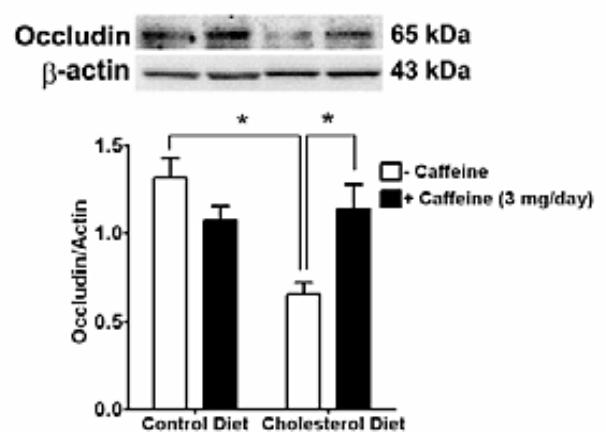

D
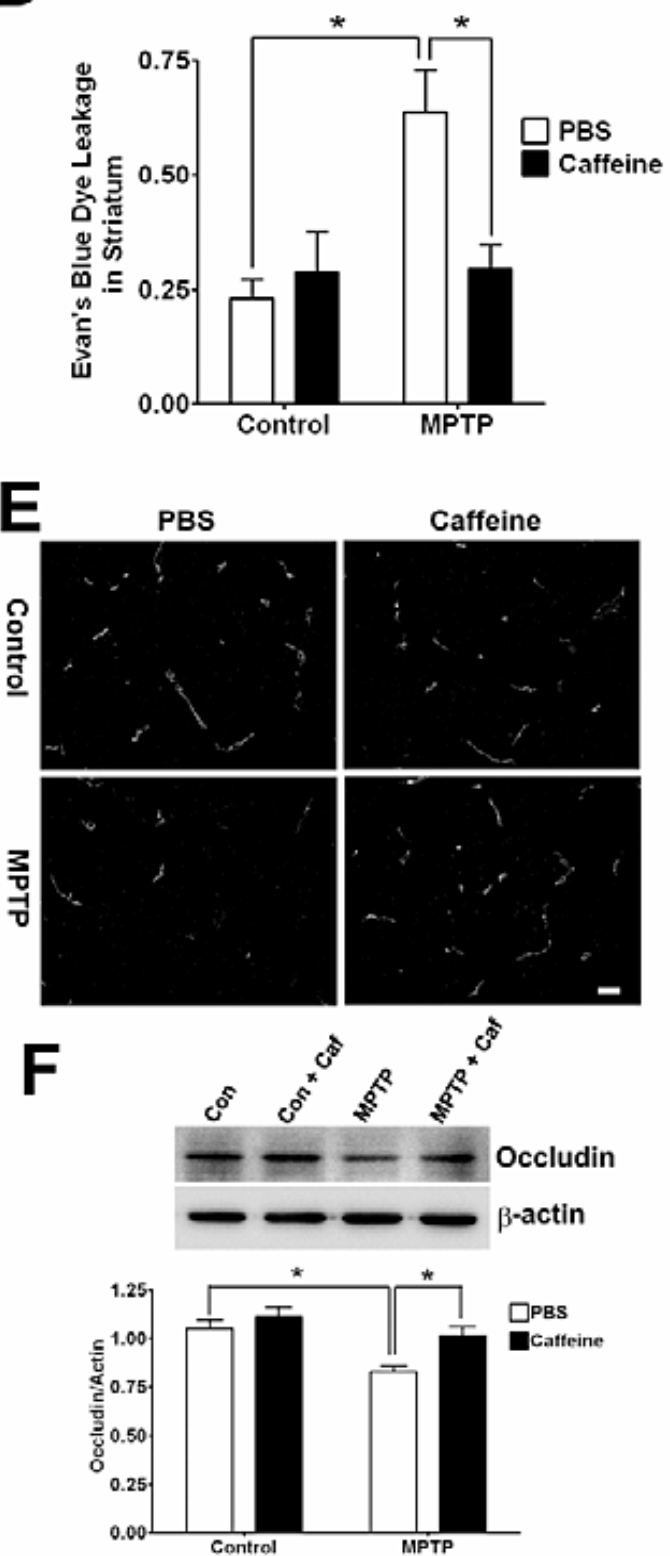

Fig. 2. In a rabbit model of sporadic AD, caffeine at a dose of $3 \mathrm{mg} /$ day blocked cholesterol-enriched diet-induced increases in leakage of Evan's blue dye (A) and decreases in occludin immunostaining (B) and protein levels $(\mathrm{C})$ in olfactory bulb (Bar $=100 \mu \mathrm{m})$. Modified with permission from [96]. In a MPTP neurotoxin model of PD, caffeine at the dose of $10 \mathrm{mg} / \mathrm{kg} /$ day blocked MPTP-induced increases in leakage of Evan's blue dye (D) and decreases in occludin immunostaining (E) and protein levels (F) in striatum (Bar $=20 \mu$ m). Modified with permission from [177].

known to block can inhibit neuroinflammation in in vitro models devoid of BBB [199-201]. Therefore, the protective effects of caffeine against BBB leakage might result from its ability to inhibit neuroinflammation. The anti-inflammatory actions of caffeine may also involve blockade of adenosine $\mathrm{A}_{2 A}$ receptors out- side of the brain [202], which could limit brain cytokine up-regulation (eg. interleukin-1) known to accompany brain insults, including AD [203]. In addition, caffeine has been shown to have direct neuroprotective effects and it remains a possibility that caffeine's protective effects against BBB leakage are secondary to its neu- 
roprotective effects. However, we do favor the notion that neuroprotection is secondary to the BBB effects because of our findings in a rabbit model of sporadic $\mathrm{AD}$ that caffeine can protect against increased BBB leakage in the absence of apparent neuronal loss by the cholesterol-enriched diet [96].

It is becoming increasing clear that synaptic dysfunction is the key event in pathogenesis of both AD and PD. In AD patients, it is the loss of synapses rather than neurons that effectively correlates with dementia [204,205]. In AD animal models, there is hardly any neuronal loss, but synaptic loss and dendritic spine abnormalities have been demonstrated in several transgenic mouse models of AD [206-208]. Altered synaptic plasticity has also been demonstrated in PD patients [209] and in PD animal models [210213]. As mentioned earlier, the BBB limits the entry of blood-borne pathogens, substances, drugs, and cells into brain parenchyma and helps regulate and protect the microenvironment of the brain such that once the $\mathrm{BBB}$ is disrupted, synaptic and neuronal functions are compromised [5]. In the cholesterol-fed rabbit model of $\mathrm{AD}$, both $\mathrm{BBB}$ disruption and learning deficit have been demonstrated $[95,96]$. Furthermore, our observation that caffeine protects against BBB disruption is consistent with the findings that caffeine intake protects against memory loss in aging and in AD [150, 151]. Thus, synaptic dysfunction and loss of synaptic markers should be a focus in future studies using the rabbit model of $\mathrm{AD}$.

\section{CONCLUSIONS}

Sporadic AD and PD are the two most common neurodegenerative diseases, with unknown etiologies and limited available therapeutic interventions. Recent epidemiological and experimental studies suggest strongly that caffeine, the most commonly ingested psychoactive drug in the world, is protective against these degenerative diseases. Furthermore, elucidating underlying mechanisms whereby caffeine protects against AD and PD will undoubtedly lead to new therapeutic strategies that could prevent, delay, and/or treat these deleterious diseases.

Emerging evidence suggests that BBB dysfunction plays an important role in the pathogenesis of both $\mathrm{AD}$ and PD. Our recent findings that caffeine, a safe and readily available drug, can stabilize $\mathrm{BBB}$, have important implications for therapeutic interventions against these neurological disorders. Nevertheless, further detailed studies are now warranted to determine first the temporal and spatial sequence of caffeine's effects on BBB leakage, neuroinflammation, synaptic dysfunction, and neuroprotection, and second the detailed molecular mechanism(s) whereby caffeine protects against BBB disruption. However, because caffeine can prevent the opening of the BBB in two very different models of neurodegenerative disorders and in two different species and therefore may be of generalized importance, it might be important to limit ingestion of caffeine by patients undergoing therapeutic interventions wherein controlled opening of the BBB is integral to the desired clinical endpoints.

\section{ACKNOWLEDGMENTS}

This work was supported by P20RR17699 from the US National Center for Research Resources, a component of the National Institutes of Health.

Authors' disclosures available online (http://www.jalz.com/disclosures/view.php?id=250).

\section{REFERENCES}

[1] Gloor SM, Wachtel M, Bolliger MF, Ishihara H, Landmann R, Frei K (2001) Molecular and cellular permeability control at the blood-brain barrier. Brain Res Brain Res Rev 36, 258264.

[2] Reese TS, Karnovsky MJ (1967) Fine structural localization of a blood-brain barrier to exogenous peroxidase. J Cell Biol 34, 207-217.

[3] Turksen K, Troy TC (2004) Barriers built on claudins. J Cell Sci 117, 2435-2447.

[4] Abbott NJ (2005) Dynamics of CNS barriers: evolution, differentiation, and modulation. Cell Mol Neurobiol 25, 5-23.

[5] Zlokovic BV (2008) The blood-brain barrier in health and chronic neurodegenerative disorders. Neuron 57, 178-201.

[6] Vorbrodt AW, Dobrogowska DH (2003) Molecular anatomy of intercellular junctions in brain endothelial and epithelial barriers: electron microscopist's view. Brain Res Brain Res Rev 42, 221-242.

[7] Ando-Akatsuka Y, Saitou M, Hirase T, Kishi M, Sakakibara A, Itoh M, Yonemura S, Furuse M, Tsukita S (1996) Interspecies diversity of the occludin sequence: cDNA cloning of human, mouse, dog, and rat-kangaroo homologues. J Cell Biol 133, 43-47.

[8] Furuse M, Hirase T, Itoh M, Nagafuchi A, Yonemura S, Tsukita S, Tsukita S (1993) Occludin: a novel integral membrane protein localizing at tight junctions. J Cell Biol 123, 1777-1788.

[9] Hirase T, Staddon JM, Saitou M, Ando-Akatsuka Y, Itoh M, Furuse M, Fujimoto K, Tsukita S, Rubin LL (1997) Occludin as a possible determinant of tight junction permeability in endothelial cells. J Cell Sci 110(Pt 14), 1603-1613. 
[10] Morita K, Sasaki H, Furuse M, Tsukita S (1999) Endothelial claudin: claudin-5/TMVCF constitutes tight junction strands in endothelial cells. J Cell Biol 147, 185-194.

[11] Citi S, Sabanay H, Jakes R, Geiger B, Kendrick-Jones J (1988) Cingulin, a new peripheral component of tight junctions. Nature 333, 272-276.

[12] Stevenson BR, Heintzelman MB, Anderson JM, Citi S, Mooseker MS (1989) ZO-1 and cingulin: tight junction proteins with distinct identities and localizations. Am J Physiol 257, C621-628

[13] Fischer S, Wobben M, Marti HH, Renz D, Schaper W (2002) Hypoxia-induced hyperpermeability in brain microvessel endothelial cells involves VEGF-mediated changes in the expression of zonula occludens-1. Microvasc Res 63, 70-80.

[14] Abbruscato TJ, Lopez SP, Mark KS, Hawkins BT, Davis TP (2002) Nicotine and cotinine modulate cerebral microvascular permeability and protein expression of ZO-1 through nicotinic acetylcholine receptors expressed on brain endothelial cells. J Pharm Sci 91, 2525-2538.

[15] Inoko A, Itoh M, Tamura A, Matsuda M, Furuse M, Tsukita S (2003) Expression and distribution of ZO-3, a tight junction MAGUK protein, in mouse tissues. Genes Cells $\mathbf{8}, 837-845$.

[16] Wolburg H, Lippoldt A (2002) Tight junctions of the bloodbrain barrier: development, composition and regulation. Vascul Pharmacol 38, 323-337.

[17] Ishizaki T, Chiba H, Kojima T, Fujibe M, Soma T, Miyajima H, Nagasawa K, Wada I, Sawada N (2003) Cyclic AMP induces phosphorylation of claudin- 5 immunoprecipitates and expression of claudin-5 gene in blood-brain-barrier endothelial cells via protein kinase A-dependent and -independent pathways. Exp Cell Res 290, 275-288.

[18] Andreeva AY, Krause E, Muller EC, Blasig IE, Utepbergenov DI (2001) Protein kinase $C$ regulates the phosphorylation and cellular localization of occludin. J Biol Chem 276, 3848038486.

[19] Farshori P, Kachar B (1999) Redistribution and phosphorylation of occludin during opening and resealing of tight junctions in cultured epithelial cells. J Membr Biol 170, 147-156.

[20] Sakakibara A, Furuse M, Saitou M, Ando-Akatsuka Y, Tsukita $S$ (1997) Possible involvement of phosphorylation of occludin in tight junction formation. J Cell Biol 137, 13931401.

[21] Yamamoto M, Ramirez SH, Sato S, Kiyota T, Cerny RL, Kaibuchi K, Persidsky Y, Ikezu T (2008) Phosphorylation of claudin-5 and occludin by rho kinase in brain endothelial cells. Am J Pathol 172, 521-533.

[22] Hirase T, Kawashima S, Wong EY, Ueyama T, Rikitake Y, Tsukita S, Yokoyama M, Staddon JM (2001) Regulation of tight junction permeability and occludin phosphorylation by Rhoa-p160ROCK-dependent and -independent mechanisms. J Biol Chem 276, 10423-10431.

[23] Nagy Z, Goehlert UG, Wolfe LS, Huttner I (1985) Ca2+ depletion-induced disconnection of tight junctions in isolated rat brain microvessels. Acta Neuropathol 68, 48-52.

[24] Abbott NJ (2000) Inflammatory mediators and modulation of blood-brain barrier permeability. Cell Mol Neurobiol 20 , 131-147.

[25] Abbott NJ, Revest PA (1991) Control of brain endothelial permeability. Cerebrovasc Brain Metab Rev 3, 39-72.

[26] Antonetti DA, Barber AJ, Hollinger LA, Wolpert EB, Gardner TW (1999) Vascular endothelial growth factor induces rapid phosphorylation of tight junction proteins occludin and zonula occluden 1 . A potential mechanism for vascular per- meability in diabetic retinopathy and tumors. $J$ Biol Chem 274, 23463-23467.

[27] Schreibelt G, Kooij G, Reijerkerk A, van Doorn R, Gringhuis SI, van der Pol S, Weksler BB, Romero IA, Couraud PO, Piontek J, Blasig IE, Dijkstra CD, Ronken E, de Vries H (2007) Reactive oxygen species alter brain endothelial tight junction dynamics via RhoA, PI3 kinase, and PKB signaling. FASEB J 21, 3666-3676.

[28] Jou TS, Schneeberger EE, Nelson WJ (1998) Structural and functional regulation of tight junctions by RhoA and Rac1 small GTPases. J Cell Biol 142, 101-115.

[29] Hopkins AM, Li D, Mrsny RJ, Walsh SV, Nusrat A (2000) Modulation of tight junction function by $\mathrm{G}$ protein-coupled events. Adv Drug Deliv Rev 41, 329-340.

[30] Stelzner TJ, Weil JV, O'Brien RF (1989) Role of cyclic adenosine monophosphate in the induction of endothelial barrier properties. J Cell Physiol 139, 157-166.

[31] Rubin LL, Hall DE, Porter S, Barbu K, Cannon C, Horner HC, Janatpour M, Liaw CW, Manning K, Morales J (1991) A cell culture model of the blood-brain barrier. J Cell Biol 115, 1725-1735.

[32] Wolburg H, Neuhaus J, Kniesel U, Krauss B, Schmid EM, Ocalan M, Farrell C, Risau W (1994) Modulation of tight junction structure in blood-brain barrier endothelial cells. Effects of tissue culture, second messengers and cocultured astrocytes. J Cell Sci 107(Pt 5), 1347-1357.

[33] Hoane MR, Kaplan SA, Ellis AL (2006) The effects of nicotinamide on apoptosis and blood-brain barrier breakdown following traumatic brain injury. Brain Res 1125, 185-193.

[34] McGill JK, Gallagher L, Carswell HV, Irving EA, Dominiczak AF, Macrae IM (2005) Impaired functional recovery after stroke in the stroke-prone spontaneously hypertensive rat. Stroke 36, 135-141.

[35] Minagar A, Alexander JS (2003) Blood-brain barrier disruption in multiple sclerosis. Mult Scler 9, 540-549.

[36] Petito CK, Cash KS (1992) Blood-brain barrier abnormalities in the acquired immunodeficiency syndrome: immunohistochemical localization of serum proteins in postmortem brain. Ann Neurol 32, 658-666.

[37] Zipser BD, Johanson CE, Gonzalez L, Berzin TM, Tavares R, Hulette CM, Vitek MP, Hovanesian V, Stopa EG (2007) Microvascular injury and blood-brain barrier leakage in Alzheimer's disease. Neurobiol Aging 28, 977-986.

[38] Kortekaas R, Leenders KL, van Oostrom JC, Vaalburg W, Bart J, Willemsen AT, Hendrikse NH (2005) Blood-brain barrier dysfunction in parkinsonian midbrain in vivo. Ann Neurol 57, 176-179.

[39] Wenk GL (2003) Neuropathologic changes in Alzheimer's disease. J Clin Psychiatry 64(Suppl 9), 7-10.

[40] Hardy J, Allsop D (1991) Amyloid deposition as the central event in the aetiology of Alzheimer's disease. Trends Pharmacol Sci 12, 383-388.

[41] Hardy J, Selkoe DJ (2002) The amyloid hypothesis of Alzheimer's disease: progress and problems on the road to therapeutics. Science 297, 353-356.

[42] Blennow K, de Leon MJ, Zetterberg H (2006) Alzheimer's disease. Lancet 368, 387-403.

[43] Knottnerus IL, Ten Cate H, Lodder J, Kessels F, van Oostenbrugge RJ (2009) Endothelial dysfunction in lacunar stroke: a systematic review. Cerebrovasc Dis 27, 519-526.

[44] Taguchi A (2009) Vascular factors in diabetes and Alzheimer's disease. J Alzheimers Dis 16, 859-864.

[45] Huber JD (2008) Diabetes, cognitive function, and the bloodbrain barrier. Curr Pharm Des 14, 1594-1600. 
[46] Rapp JH, Pan XM, Neumann M, Hong M, Hollenbeck K, Liu J (2008) Microemboli composed of cholesterol crystals disrupt the blood-brain barrier and reduce cognition. Stroke 39, 2354-2361.

[47] Alafuzoff I, Adolfsson R, Grundke-Iqbal I, Winblad B (1987) Blood-brain barrier in Alzheimer dementia and in nondemented elderly. An immunocytochemical study. Acta Neuropathol 73, 160-166.

[48] Kalaria RN (1999) The blood-brain barrier and cerebrovascular pathology in Alzheimer's disease. Ann N Y Acad Sci 893, 113-125.

[49] Kalaria RN (1992) The blood-brain barrier and cerebral microcirculation in Alzheimer disease. Cerebrovasc Brain Metab Rev 4, 226-260.

[50] Munoz DG, Erkinjuntti T, Gaytan-Garcia S, Hachinski V (1997) Serum protein leakage in Alzheimer's disease revisited. Ann N Y Acad Sci 826, 173-189.

[51] Skoog I, Wallin A, Fredman P, Hesse C, Aevarsson O, Karlsson I, Gottfries CG, Blennow K (1998) A population study on blood-brain barrier function in 85-year-olds: relation to Alzheimer's disease and vascular dementia. Neurology 50, 966-971.

[52] Blennow K, Wallin A, Fredman P, Karlsson I, Gottfries CG, Svennerholm L (1990) Blood-brain barrier disturbance in patients with Alzheimer's disease is related to vascular factors. Acta Neurol Scand 81, 323-326.

[53] Algotsson A, Winblad B (2007) The integrity of the bloodbrain barrier in Alzheimer's disease. Acta Neurol Scand 115, 403-408.

[54] Bowman GL, Kaye JA, Moore M, Waichunas D, Carlson NE, Quinn JF (2007) Blood-brain barrier impairment in Alzheimer disease: stability and functional significance. Neurology 68, 1809-1814.

[55] Farkas E, Luiten PG (2001) Cerebral microvascular pathology in aging and Alzheimer's disease. Prog Neurobiol 64, 575-611.

[56] Ujiie M, Dickstein DL, Carlow DA, Jefferies WA (2003) Blood-brain barrier permeability precedes senile plaque formation in an Alzheimer disease model. Microcirculation 10, 463-470.

[57] Deane R, Du Yan S, Submamaryan RK, LaRue B, Jovanovic S, Hogg E, Welch D, Manness L, Lin C, Yu J, Zhu H, Ghiso J, Frangione B, Stern A, Schmidt AM, Armstrong DL, Arnold B, Liliensiek B, Nawroth P, Hofman F, Kindy M, Stern D, Zlokovic B (2003) RAGE mediates amyloid-beta peptide transport across the blood-brain barrier and accumulation in brain. Nat Med 9, 907-913.

[58] Deane R, Wu Z, Sagare A, Davis J, Du Yan S, Hamm K, Xu F, Parisi M, LaRue B, Hu HW, Spijkers P, Guo H, Song X, Lenting PJ, Van Nostrand WE, Zlokovic BV (2004) LRP/amyloid beta-peptide interaction mediates differential brain efflux of Abeta isoforms. Neuron 43, 333-344.

[59] Deane R, Zlokovic BV (2007) Role of the blood-brain barrier in the pathogenesis of Alzheimer's disease. Curr Alzheimer Res 4, 191-197.

[60] Zlokovic BV (1996) Cerebrovascular transport of Alzheimer's amyloid beta and apolipoproteins J and E: possible anti-amyloidogenic role of the blood-brain barrier. Life Sci 59, 1483-1497.

[61] Deane R, Sagare A, Hamm K, Parisi M, Lane S, Finn MB, Holtzman DM, Zlokovic BV (2008) apoE isoform-specific disruption of amyloid beta peptide clearance from mouse brain. J Clin Invest 118, 4002-4013.
[62] Selkoe DJ (2001) Clearing the brain's amyloid cobwebs. Neuron 32, 177-180.

[63] Shibata M, Yamada S, Kumar SR, Calero M, Bading J, Frangione B, Holtzman DM, Miller CA, Strickland DK, Ghiso J, Zlokovic BV (2000) Clearance of Alzheimer's amyloid-ss(140) peptide from brain by LDL receptor-related protein-1 at the blood-brain barrier. J Clin Invest 106, 1489-1499.

[64] Zlokovic BV, Martel CL, Matsubara E, McComb JG, Zheng G, McCluskey RT, Frangione B, Ghiso J (1996) Glycoprotein 330/megalin: probable role in receptor-mediated transport of apolipoprotein $\mathrm{J}$ alone and in a complex with Alzheimer disease amyloid beta at the blood-brain and blood-cerebrospinal fluid barriers. Proc Natl Acad Sci U S A 93, 4229-4234.

[65] Tang K, Hynan LS, Baskin F, Rosenberg RN (2006) Platelet amyloid precursor protein processing: a bio-marker for Alzheimer's disease. J Neurol Sci 240, 53-58.

[66] Kuo YM, Emmerling MR, Lampert HC, Hempelman SR, Kokjohn TA, Woods AS, Cotter RJ, Roher AE (1999) High levels of circulating Abeta42 are sequestered by plasma proteins in Alzheimer's disease. Biochem Biophys Res Commun 257, 787-791.

[67] Kuo YM, Kokjohn TA, Watson MD, Woods AS, Cotter RJ, Sue LI, Kalback WM, Emmerling MR, Beach TG, Roher AE (2000) Elevated abeta42 in skeletal muscle of Alzheimer disease patients suggests peripheral alterations of AbetaPP metabolism. Am J Pathol 156, 797-805.

[68] Kalaria RN, Premkumar DR, Pax AB, Cohen DL, Lieberburg I (1996) Production and increased detection of amyloid beta protein and amyloidogenic fragments in brain microvessels, meningeal vessels and choroid plexus in Alzheimer's disease. Brain Res Mol Brain Res 35, 58-68.

[69] Natte R, de Boer WI, Maat-Schieman ML, Baelde HJ, Vinters HV, Roos RA, van Duinen SG (1999) Amyloid beta precursor protein-mRNA is expressed throughout cerebral vessel walls. Brain Res 828, 179-183.

[70] Miklossy J (2008) Chronic inflammation and amyloidogenesis in Alzheimer's disease - role of Spirochetes. J Alzheimers Dis 13, 381-391.

[71] Farkas IG, Czigner A, Farkas E, Dobo E, Soos K, Penke B, Endresz V, Mihaly A (2003) Beta-amyloid peptide-induced blood-brain barrier disruption facilitates T-cell entry into the rat brain. Acta Histochem 105, 115-125.

[72] Racke MM, Boone LI, Hepburn DL, Parsadainian M, Bryan MT, Ness DK, Piroozi KS, Jordan WH, Brown DD, Hoffman WP, Holtzman DM, Bales KR, Gitter BD, May PC, Paul SM, DeMattos RB (2005) Exacerbation of cerebral amyloid angiopathy-associated microhemorrhage in amyloid precursor protein transgenic mice by immunotherapy is dependent on antibody recognition of deposited forms of amyloid beta. J Neurosci 25, 629-636.

[73] Dickstein DL, Biron KE, Ujiie M, Pfeifer CG, Jeffries AR, Jefferies WA (2006) Abeta peptide immunization restores blood-brain barrier integrity in Alzheimer disease. FASEB $J$ 20, 426-433.

[74] Jancso G, Domoki F, Santha P, Varga J, Fischer J, Orosz K, Penke B, Becskei A, Dux M, Toth L (1998) Beta-amyloid (1-42) peptide impairs blood-brain barrier function after intracarotid infusion in rats. Neurosci Lett 253, 139-141.

[75] Eisenhauer PB, Johnson RJ, Wells JM, Davies TA, Fine RE (2000) Toxicity of various amyloid beta peptide species in cultured human blood-brain barrier endothelial cells: increased toxicity of dutch-type mutant. J Neurosci Res $\mathbf{6 0}$, 804-810. 
[76] Sparks DL, Martin TA, Gross DR, Hunsaker JC, 3rd (2000) Link between heart disease, cholesterol, and Alzheimer's disease: a review. Microsc Res Tech 50, 287-290.

[77] Kivipelto M, Helkala EL, Hanninen T, Laakso MP, Hallikainen M, Alhainen K, Soininen H, Tuomilehto J, Nissinen A (2001) Midlife vascular risk factors and late-life mild cognitive impairment: A population-based study. Neurology 56, 1683-1689.

[78] Sjogren M, Mielke M, Gustafson D, Zandi P, Skoog I (2006) Cholesterol and Alzheimer's disease - is there a relation? Mech Ageing Dev 127, 138-147.

[79] Jurevics H, Morell P (1995) Cholesterol for synthesis of myelin is made locally, not imported into brain. J Neurochem 64, 895-901.

[80] Maxfield FR, Tabas I (2005) Role of cholesterol and lipid organization in disease. Nature 438, 612-621.

[81] Marzolo MP, Bu G (2009) Lipoprotein receptors and cholesterol in APP trafficking and proteolytic processing, implications for Alzheimer's disease. Semin Cell Dev Biol 20, 191-200.

[82] Sing CF, Davignon J (1985) Role of the apolipoprotein E polymorphism in determining normal plasma lipid and lipoprotein variation. Am J Hum Genet 37, 268-285.

[83] Corder EH, Saunders AM, Strittmatter WJ, Schmechel DE, Gaskell PC, Small GW, Roses AD, Haines JL, Pericak-Vance MA (1993) Gene dose of apolipoprotein E type 4 allele and the risk of Alzheimer's disease in late onset families. Science 261, 921-923.

[84] Hofman A, Ott A, Breteler MM, Bots ML, Slooter AJ, van Harskamp F, van Duijn CN, Van Broeckhoven C, Grobbee DE (1997) Atherosclerosis, apolipoprotein E, and prevalence of dementia and Alzheimer's disease in the Rotterdam Study. Lancet 349, 151-154.

[85] Notkola IL, Sulkava R, Pekkanen J, Erkinjuntti T, Ehnholm C, Kivinen P, Tuomilehto J, Nissinen A (1998) Serum total cholesterol, apolipoprotein E epsilon 4 allele, and Alzheimer's disease. Neuroepidemiology 17, 14-20.

[86] Sparks DL, Scheff SW, Hunsaker JC, 3rd, Liu H, Landers T, Gross DR (1994) Induction of Alzheimer-like beta-amyloid immunoreactivity in the brains of rabbits with dietary cholesterol. Exp Neurol 126, 88-94.

[87] Simons M, Keller P, De Strooper B, Beyreuther K, Dotti CG, Simons K (1998) Cholesterol depletion inhibits the generation of beta-amyloid in hippocampal neurons. Proc Natl Acad Sci U S A 95, 6460-6464.

[88] Frears ER, Stephens DJ, Walters CE, Davies H, Austen BM (1999) The role of cholesterol in the biosynthesis of betaamyloid. Neuroreport 10, 1699-1705.

[89] Fassbender K, Simons M, Bergmann C, Stroick M, Lutjohann D, Keller P, Runz H, Kuhl S, Bertsch T, von Bergmann K, Hennerici M, Beyreuther K, Hartmann T (2001) Simvastatin strongly reduces levels of Alzheimer's disease beta -amyloid peptides Abeta 42 and Abeta 40 in vitro and in vivo. Proc Natl Acad Sci U S A 98, 5856-5861.

[90] Jick H, Zornberg GL, Jick SS, Seshadri S, Drachman DA (2000) Statins and the risk of dementia. Lancet 356, 1627 1631.

[91] Wolozin B, Kellman W, Ruosseau P, Celesia GG, Siegel G (2000) Decreased prevalence of Alzheimer disease associated with 3-hydroxy-3-methyglutaryl coenzyme A reductase inhibitors. Arch Neurol 57, 1439-1443.

[92] Ghribi O, Golovko MY, Larsen B, Schrag M, Murphy EJ (2006) Deposition of iron and beta-amyloid plaques is asso- ciated with cortical cellular damage in rabbits fed with longterm cholesterol-enriched diets. J Neurochem 99, 438-449.

[93] Ghribi O, Larsen B, Schrag M, Herman MM (2006) High cholesterol content in neurons increases BACE, betaamyloid, and phosphorylated tau levels in rabbit hippocampus. Exp Neurol 200, 460-467.

[94] Woodruff-Pak DS, Agelan A, Del Valle L (2007) A rabbit model of Alzheimer's disease: valid at neuropathological, cognitive, and therapeutic levels. J Alzheimers Dis 11, 371383.

[95] Sparks DL, Schreurs BG (2003) Trace amounts of copper in water induce beta-amyloid plaques and learning deficits in a rabbit model of Alzheimer's disease. Proc Natl Acad Sci U S A 100, 11065-11069.

[96] Chen X, Gawryluk JW, Wagener JF, Ghribi O, Geiger JD (2008) Caffeine blocks disruption of blood brain barrier in a rabbit model of Alzheimer's disease. J Neuroinflammation 5, 12.

[97] Ferreira A, Caceres A, Kosik KS (1993) Intraneuronal compartments of the amyloid precursor protein. J Neurosci 13, 3112-3123.

[98] Perez RG, Soriano S, Hayes JD, Ostaszewski B, Xia W, Selkoe DJ, Chen X, Stokin GB, Koo EH (1999) Mutagenesis identifies new signals for beta-amyloid precursor protein endocytosis, turnover, and the generation of secreted fragments, including Abeta42. J Biol Chem 274, 18851-18856.

[99] Soriano S, Chyung AS, Chen X, Stokin GB, Lee VM, Koo EH (1999) Expression of beta-amyloid precursor proteinCD3gamma chimeras to demonstrate the selective generation of amyloid beta(1-40) and amyloid beta(1-42) peptides within secretory and endocytic compartments. J Biol Chem 274, 32295-32300.

[100] Chyung JH, Selkoe DJ (2003) Inhibition of receptormediated endocytosis demonstrates generation of amyloid beta-protein at the cell surface. J Biol Chem 278, 5103551043.

[101] Vassar R, Bennett BD, Babu-Khan S, Kahn S, Mendiaz EA, Denis P, Teplow DB, Ross S, Amarante P, Loeloff R, Luo Y, Fisher S, Fuller J, Edenson S, Lile J, Jarosinski MA, Biere AL, Curran E, Burgess T, Louis JC, Collins F, Treanor J, Rogers G, Citron M (1999) Beta-secretase cleavage of Alzheimer's amyloid precursor protein by the transmembrane aspartic protease BACE. Science 286, 735-741.

[102] Shimizu H, Tosaki A, Kaneko K, Hisano T, Sakurai T, Nukina N (2008) Crystal structure of an active form of BACE1, an enzyme responsible for amyloid beta protein production. $\mathrm{Mol}$ Cell Biol 28, 3663-3671.

[103] Rajendran L, Schneider A, Schlechtingen G, Weidlich S, Ries J, Braxmeier T, Schwille P, Schulz JB, Schroeder C, Simons M, Jennings G, Knölker HJ, Simons K (2008) Efficient inhibition of the Alzheimer's disease beta-secretase by membrane targeting. Science 320, 520-523.

[104] Cataldo AM, Petanceska S, Terio NB, Peterhoff CM, Durham R, Mercken M, Mehta PD, Buxbaum J, Haroutunian V, Nixon RA (2004) Abeta localization in abnormal endosomes: association with earliest Abeta elevations in AD and Down syndrome. Neurobiol Aging 25, 1263-1272.

[105] Cataldo AM, Peterhoff CM, Troncoso JC, Gomez-Isla T, Hyman BT, Nixon RA (2000) Endocytic pathway abnormalities precede amyloid beta deposition in sporadic Alzheimer's disease and Down syndrome: differential effects of APOE genotype and presenilin mutations. Am J Pathol 157, 277286. 
[106] Ohyagi Y (2008) Intracellular amyloid beta-protein as a therapeutic target for treating Alzheimer's disease. Curr Alzheimer Res 5, 555-561.

[107] Vance JE, Karten B, Hayashi H (2006) Lipid dynamics in neurons. Biochem Soc Trans 34, 399-403.

[108] Meresse S, Delbart C, Fruchart JC, Cecchelli R (1989) Lowdensity lipoprotein receptor on endothelium of brain capillaries. J Neurochem 53, 340-345.

[109] Dehouck B, Fenart L, Dehouck MP, Pierce A, Torpier G, Cecchelli R (1997) A new function for the LDL receptor: transcytosis of LDL across the blood-brain barrier. $J$ Cell Biol 138, 877-889.

[110] Ignatius MJ, Gebicke-Haerter PJ, Pitas RE, Shooter EM (1987) Apolipoprotein E in nerve injury and repair. Prog Brain Res 71, 177-184.

[111] Swanson LW, Simmons DM, Hofmann SL, Goldstein JL, Brown MS (1988) Localization of mRNA for low density lipoprotein receptor and a cholesterol synthetic enzyme in rabbit nervous system by in situ hybridization. Proc Natl Acad Sci U S A 85, 9821-9825.

[112] Beffert U, Danik M, Krzywkowski P, Ramassamy C, Berrada F, Poirier J (1998) The neurobiology of apolipoproteins and their receptors in the CNS and Alzheimer's disease. Brain Res Brain Res Rev 27, 119-142.

[113] Waldron E, Jaeger S, Pietrzik CU (2006) Functional role of the low-density lipoprotein receptor-related protein in Alzheimer's disease. Neurodegener Dis 3, 233-238.

[114] Pietrzik CU, Busse T, Merriam DE, Weggen S, Koo EH (2002) The cytoplasmic domain of the LDL receptor-related protein regulates multiple steps in APP processing. Embo J 21, 5691-5700.

[115] Pietrzik CU, Yoon IS, Jaeger S, Busse T, Weggen S, Koo EH (2004) FE65 constitutes the functional link between the lowdensity lipoprotein receptor-related protein and the amyloid precursor protein. $J$ Neurosci $\mathbf{2 4}, 4259-4265$.

[116] Bu G, Cam J, Zerbinatti C (2006) LRP in amyloid-beta production and metabolism. Ann N Y Acad Sci 1086, 35-53.

[117] Kounnas MZ, Moir RD, Rebeck GW, Bush AI, Argraves WS, Tanzi RE, Hyman BT, Strickland DK (1995) LDL receptorrelated protein, a multifunctional ApoE receptor, binds secreted beta-amyloid precursor protein and mediates its degradation. Cell 82, 331-340.

[118] Ulery PG, Beers J, Mikhailenko I, Tanzi RE, Rebeck GW, Hyman BT, Strickland DK (2000) Modulation of beta-amyloid precursor protein processing by the low density lipoprotein receptor-related protein (LRP). Evidence that LRP contributes to the pathogenesis of Alzheimer's disease. $J$ Biol Chem 275, 7410-7415.

[119] Holland JA, Pritchard KA, Rogers NJ, Stemerman MB (1992) Atherogenic levels of low-density lipoprotein increase endocytotic activity in cultured human endothelial cells. Am J Pathol 140, 551-558.

[120] Guretzki HJ, Gerbitz KD, Olgemoller B, Schleicher E (1994) Atherogenic levels of low density lipoprotein alter the permeability and composition of the endothelial barrier. Atherosclerosis $\mathbf{1 0 7}, 15-24$

[121] Calne DB, Langston JW (1983) Aetiology of Parkinson's disease. Lancet 2, 1457-1459.

[122] Hunot S, Hirsch EC (2003) Neuroinflammatory processes in Parkinson's disease. Ann Neurol 53 Suppl 3, S49-58; discussion S58-60.

[123] Rogers J, Kovelowski CJ (2003) Inflammatory Mechanisms in Parkinson's Disease In Neuroinflammation, 2nd Edition:
Mechanisms and Management, Wood PL, ed. Humana Press Inc., Totowa, NJ, pp. 391-403.

124] Hawkins BT, Davis TP (2005) The blood-brain barrier/neurovascular unit in health and disease. Pharmacol Rev 57, 173-185.

[125] Abbott NJ, Ronnback L, Hansson E (2006) Astrocyteendothelial interactions at the blood-brain barrier. Nat Rev Neurosci 7, 41-53.

[126] Stolp HB, Dziegielewska KM (2009) Review: Role of developmental inflammation and blood-brain barrier dysfunction in neurodevelopmental and neurodegenerative diseases. Neuropathol Appl Neurobiol 35, 132-146.

[127] Weiss N, Miller F, Cazaubon S, Couraud PO (2009) The blood-brain barrier in brain homeostasis and neurological diseases. Biochim Biophys Acta 1788, 842-857.

[128] Gupta A, Agarwal R, Shukla GS (1999) Functional impairment of blood-brain barrier following pesticide exposure during early development in rats. Hum Exp Toxicol 18, 174-179.

[129] Behzadian MA, Wang XL, Windsor LJ, Ghaly N, Caldwell RB (2001) TGF-beta increases retinal endothelial cell permeability by increasing MMP-9: possible role of glial cells in endothelial barrier function. Invest Ophthalmol Vis Sci $\mathbf{4 2}$, 853-859.

[130] Pflugfelder SC, Farley W, Luo L, Chen LZ, de Paiva CS, Olmos LC, Li DQ, Fini ME (2005) Matrix metalloproteinase9 knockout confers resistance to corneal epithelial barrier disruption in experimental dry eye. Am J Pathol 166, 61-71.

[131] Asahi M, Wang X, Mori T, Sumii T, Jung JC, Moskowitz MA, Fini ME, Lo EH (2001) Effects of matrix metalloproteinase-9 gene knock-out on the proteolysis of blood-brain barrier and white matter components after cerebral ischemia. $J$ Neurosci 21, 7724-7732.

132] Petty MA, Lo EH (2002) Junctional complexes of the bloodbrain barrier: permeability changes in neuroinflammation. Prog Neurobiol 68, 311-323.

[133] Zhao C, Ling Z, Newman MB, Bhatia A, Carvey PM (2007) TNF-alpha knockout and minocycline treatment attenuates blood-brain barrier leakage in MPTP-treated mice. Neurobiol Dis 26, 36-46.

[134] Faucheux BA, Bonnet AM, Agid Y, Hirsch EC (1999) Blood vessels change in the mesencephalon of patients with Parkinson's disease. Lancet 353, 981-982.

[135] Carvey PM, Zhao CH, Hendey B, Lum H, Trachtenberg J, Desai BS, Snyder J, Zhu YG, Ling ZD (2005) 6Hydroxydopamine-induced alterations in blood-brain barrier permeability. Eur J Neurosci 22, 1158-1168.

[136] Rite I, Machado A, Cano J, Venero JL (2007) Blood-brain barrier disruption induces in vivo degeneration of nigral dopaminergic neurons. J Neurochem 101, 1567-1582.

[137] Fredholm BB, Battig K, Holmen J, Nehlig A, Zvartau EE (1999) Actions of caffeine in the brain with special reference to factors that contribute to its widespread use. Pharmacol Rev 51, 83-133.

[138] Nehlig A, Daval JL, Debry G (1992) Caffeine and the central nervous system: mechanisms of action, biochemical, metabolic and psychostimulant effects. Brain Res Brain Res Rev 17, 139-170.

[139] Olah ME, Stiles GL (1995) Adenosine receptor subtypes: characterization and therapeutic regulation. Annu Rev Pharmacol Toxicol 35, 581-606.

[140] Jacobson KA, von Lubitz DK, Daly JW, Fredholm BB (1996) Adenosine receptor ligands: differences with acute versus chronic treatment. Trends Pharmacol Sci 17, 108-113. 
[141] Varani K, Portaluppi F, Merighi S, Ongini E, Belardinelli L, Borea PA (1999) Caffeine alters A2A adenosine receptors and their function in human platelets. Circulation 99, 24992502.

[142] Biaggioni I, Paul S, Puckett A, Arzubiaga C (1991) Caffeine and theophylline as adenosine receptor antagonists in humans. J Pharmacol Exp Ther 258, 588-593.

[143] Fredholm BB, Hedqvist P (1980) Modulation of neurotransmission by purine nucleotides and nucleosides. Biochem Pharmacol 29, 1635-1643.

[144] Dall'Igna OP, Porciuncula LO, Souza DO, Cunha RA, Lara DR (2003) Neuroprotection by caffeine and adenosine A2A receptor blockade of beta-amyloid neurotoxicity. Br J Pharmacol 138, 1207-1209.

[145] Rudolphi KA, Keil M, Fastbom J, Fredholm BB (1989) Ischaemic damage in gerbil hippocampus is reduced following upregulation of adenosine (A1) receptors by caffeine treatment. Neurosci Lett 103, 275-280.

[146] Sutherland GR, Peeling J, Lesiuk HJ, Brownstone RM, Rydzy M, Saunders JK, Geiger JD (1991) The effects of caffeine on ischemic neuronal injury as determined by magnetic resonance imaging and histopathology. Neuroscience $\mathbf{4 2}$, 171-182.

[147] Bona E, Aden U, Fredholm BB, Hagberg H (1995) The effect of long term caffeine treatment on hypoxic-ischemic brain damage in the neonate. Pediatr Res 38, 312-318.

[148] Lindsay J, Laurin D, Verreault R, Hebert R, Helliwell B, Hill GB, McDowell I (2002) Risk factors for Alzheimer's disease: a prospective analysis from the Canadian Study of Health and Aging. Am J Epidemiol 156, 445-453.

[149] Arendash GW, Schleif W, Rezai-Zadeh K, Jackson EK, Zacharia LC, Cracchiolo JR, Shippy D, Tan J (2006) Caffeine protects Alzheimer's mice against cognitive impairment and reduces brain beta-amyloid production. Neuroscience $\mathbf{1 4 2}$, 941-952.

[150] Maia L, de Mendonca A (2002) Does caffeine intake protect from Alzheimer's disease? Eur J Neurol 9, 377-382.

[151] Ritchie K, Carriere I, de Mendonca A, Portet F, Dartigues JF, Rouaud O, Barberger-Gateau P, Ancelin ML (2007) The neuroprotective effects of caffeine: a prospective population study (the Three City Study). Neurology 69, 536-545.

[152] Benedetti MD, Bower JH, Maraganore DM, McDonnell SK Peterson BJ, Ahlskog JE, Schaid DJ, Rocca WA (2000) Smoking, alcohol, and coffee consumption preceding Parkinson's disease: a case-control study. Neurology 55, 13501358.

[153] Ross GW, Abbott RD, Petrovitch H, Morens DM, Grandinetti A, Tung KH, Tanner CM, Masaki KH, Blanchette PL, Curb JD, Popper JS, White LR (2000) Association of coffee and caffeine intake with the risk of Parkinson disease. JAMA 283, 2674-2679.

[154] Ross GW, Abbott RD, Petrovitch H, White LR, Tanner CM (2000) Relationship between caffeine intake and parkinson disease. JAMA 284, 1378-1379.

[155] Ascherio A, Zhang SM, Hernan MA, Kawachi I, Colditz GA, Speizer FE, Willett WC (2001) Prospective study of caffeine consumption and risk of Parkinson's disease in men and women. Ann Neurol 50, 56-63.

[156] Higdon JV, Frei B (2006) Coffee and health: a review of recent human research. Crit Rev Food Sci Nutr 46, 101-123.

[157] Rosso A, Mossey J, Lippa CF (2008) Caffeine: neuroprotective functions in cognition and Alzheimer's disease. Am J Alzheimers Dis Other Demen 23, 417-422.
[158] Daly JW (2007) Caffeine analogs: biomedical impact. Cell Mol Life Sci 64, 2153-2169.

159] Johnson-Kozlow M, Kritz-Silverstein D, Barrett-Connor E, Morton D (2002) Coffee consumption and cognitive function among older adults. Am J Epidemiol 156, 842-850.

[160] van Gelder BM, Buijsse B, Tijhuis M, Kalmijn S, Giampaoli S, Nissinen A, Kromhout D (2007) Coffee consumption is inversely associated with cognitive decline in elderly European men: the FINE Study. Eur J Clin Nutr 61, 226-232.

[161] van Boxtel MP, Schmitt JA, Bosma H, Jolles J (2003) The effects of habitual caffeine use on cognitive change: a longitudinal perspective. Pharmacol Biochem Behav 75, 921-927.

[162] Eskelinen MH, Ngandu T, Tuomilehto J, Soininen H, Kivipelto $\mathrm{M}$ (2009) Midlife coffee and tea drinking and the risk of late-life dementia: a population-based CAIDE study. $J$ Alzheimers Dis 16, 85-91.

[163] Arendash GW, Mori T, Cao C, Mamcarz M, Runfeldt M, Dickson A, Rezai-Zadeh K, Tan J, Citron BA, Lin X, Echeverria V, Potter H (2009) Caffeine reverses cognitive impairment and decreases brain amyloid-beta levels in aged Alzheimer's disease mice. J Alzheimers Dis 17, 661-680.

[164] Cao C, Cirrito JR, Lin X, Wang L, Verges DK, Dickson A, Mamcarz M, Zhang C, Mori T, Arendash GW, Holtzman DM, Potter H (2009) Caffeine suppresses amyloid-beta levels in plasma and brain of Alzheimer's disease transgenic mice. $J$ Alzheimers Dis 17, 681-697.

[165] Fuxe K, Ungerstedt U (1974) Action of caffeine and theophyllamine on supersensitive dopamine receptors: considerable enhancement of receptor response to treatment with DOPA and dopamine receptor agonists. Med Biol 52, 48-54.

[166] Chen JF, Xu K, Petzer JP, Staal R, Xu YH, Beilstein M, Sonsalla PK, Castagnoli K, Castagnoli N, Jr., Schwarzschild MA (2001) Neuroprotection by caffeine and A(2A) adenosine receptor inactivation in a model of Parkinson's disease. J Neurosci 21, RC143, 141-146.

[167] Geiger JD, Buscemi L, Fotheringham JA (2006) Role of Adenosine in the Control of Inflammatory Events Associated With Acute and Chronic Neurodegenerative Disorders, CRC Taylor and Francis.

[168] Schwarzschild MA (2007) Adenosine A2A antagonists as neurotherapeutics: crossing the bridge. Prog Neurobiol 83, 261-262.

[169] de Mendonca A, Sebastiao AM, Ribeiro JA (2000) Adenosine: does it have a neuroprotective role after all? Brain Res Brain Res Rev 33, 258-274.

[170] Aoyama S, Kase H, Borrelli E (2000) Rescue of locomotor impairment in dopamine D2 receptor-deficient mice by an adenosine A2A receptor antagonist. J Neurosci 20, 58485852.

[171] Ikeda K, Kurokawa M, Aoyama S, Kuwana Y (2002) Neuroprotection by adenosine A2A receptor blockade in experimental models of Parkinson's disease. J Neurochem 80, 262270.

[172] Morelli M (2003) Adenosine A2A antagonists: potential preventive and palliative treatment for Parkinson's disease. Exp Neurol 184, 20-23.

[173] Xu K, Bastia E, Schwarzschild M (2005) Therapeutic potential of adenosine A(2A) receptor antagonists in Parkinson's disease. Pharmacol Ther 105, 267-310.

[174] Pierri M, Vaudano E, Sager T, Englund U (2005) KW-6002 protects from MPTP induced dopaminergic toxicity in the mouse. Neuropharmacology 48, 517-524.

[175] LeWitt PA, Guttman M, Tetrud JW, Tuite PJ, Mori A, Chaikin P, Sussman NM (2008) Adenosine A2A receptor antagonist 
istradefylline (KW-6002) reduces "off” time in Parkinson's disease: a double-blind, randomized, multicenter clinical trial (6002-US-005). Ann Neurol 63, 295-302.

[176] Jankovic J (2008) Are adenosine antagonists, such as istradefylline, caffeine, and chocolate, useful in the treatment of Parkinson's disease? Ann Neurol 63, 267-269.

[177] Chen X, Lan X, Roche I, Liu R, Geiger JD (2008) Caffeine protects against MPTP-induced blood-brain barrier dysfunction in mouse striatum. J Neurochem 107, 1147-1157.

[178] Phillis JW (1989) Adenosine in the control of the cerebral circulation. Cerebrovasc Brain Metab Rev 1, 26-54.

[179] Schaddelee MP, Voorwinden HL, van Tilburg EW, Pateman TJ, Ijzerman AP, Danhof M, de Boer AG (2003) Functional role of adenosine receptor subtypes in the regulation of blood-brain barrier permeability: possible implications for the design of synthetic adenosine derivatives. Eur J Pharm Sci 19, 13-22.

[180] Eckle T, Faigle M, Grenz A, Laucher S, Thompson LF, Eltzschig HK (2008) A2B adenosine receptor dampens hypoxia-induced vascular leak. Blood 111, 2024-2035.

[181] Laghi Pasini F, Guideri F, Picano E, Parenti G, Petersen C, Varga A, Di Perri T (2000) Increase in plasma adenosine during brain ischemia in man: a study during transient ischemic attacks, and stroke. Brain Res Bull 51, 327-330.

[182] Frenguelli BG, Wigmore G, Llaudet E, Dale N (2007) Temporal and mechanistic dissociation of ATP and adenosine release during ischaemia in the mammalian hippocampus. $J$ Neurochem 101, 1400-1413.

[183] Pearson T, Damian K, Lynas RE, Frenguelli BG (2006) Sustained elevation of extracellular adenosine and activation of A1 receptors underlie the post-ischaemic inhibition of neuronal function in rat hippocampus in vitro. J Neurochem $\mathbf{9 7}$, 1357-1368.

[184] Pignataro G, Maysami S, Studer FE, Wilz A, Simon RP, Boison D (2008) Downregulation of hippocampal adenosine kinase after focal ischemia as potential endogenous neuroprotective mechanism. J Cereb Blood Flow Metab 28, 17-23.

[185] Folcik VA, Smith T, O'Bryant S, Kawczak JA, Zhu B, Sakurai H, Kajiwara A, Staddon JM, Glabinski A, Chernosky AL, Tani M, Johnson JM, Tuohy VK, Rubin LL, Ransohoff RM (1999) Treatment with BBB022A or rolipram stabilizes the blood-brain barrier in experimental autoimmune encephalomyelitis: an additional mechanism for the therapeutic effect of type IV phosphodiesterase inhibitors. $\mathrm{J} \mathrm{Neu}$ roimmunol 97, 119-128.

[186] van Schaick EA, Zuideveld KP, Tukker HE, Langemeijer MW, Ijzerman AP, Danhof M (1998) Metabolic and cardiovascular effects of the adenosine A1 receptor agonist N6(p-sulfophenyl)adenosine in diabetic Zucker rats: influence of the disease on the selectivity of action. J Pharmacol Exp Ther 287, 21-30.

[187] Schoelch C, Kuhlmann J, Gossel M, Mueller G, NeumannHaefelin C, Belz U, Kalisch J, Biemer-Daub G, Kramer W, Juretschke HP, Herling AW (2004) Characterization of adenosine-A1 receptor-mediated antilipolysis in rats by tissue microdialysis, $1 \mathrm{H}$-spectroscopy, and glucose clamp studies. Diabetes 53, 1920-1926.

[188] Reiss AB, Rahman MM, Chan ES, Montesinos MC, Awadallah NW, Cronstein BN (2004) Adenosine A2A receptor occupancy stimulates expression of proteins involved in reverse cholesterol transport and inhibits foam cell formation in macrophages. J Leukoc Biol 76, 727-734.
[189] Gonzalez C, Klein G, Satre M (1990) Caffeine, an inhibitor of endocytosis in Dictyostelium discoideum amoebae. $J$ Cell Physiol 144, 408-415.

[190] Aubry L, Klein G, Satre M (1993) Endo-lysosomal acidification in Dictyostelium discoideum amoebae. Effects of two endocytosis inhibitors: caffeine and cycloheximide. Eur $J$ Cell Biol 61, 225-228.

[191] Carini R, Castino R, De Cesaris MG, Splendore R, Demoz M, Albano E, Isidoro C (2004) Preconditioning-induced cytoprotection in hepatocytes requires $\mathrm{Ca}(2+)$-dependent exocytosis of lysosomes. J Cell Sci 117, 1065-1077.

[192] Liu J, Lu W, Reigada D, Nguyen J, Laties AM, Mitchell $\mathrm{CH}$ (2008) Restoration of lysosomal pH in RPE cells from cultured human and $\mathrm{ABCA} 4(-/-)$ mice: pharmacologic approaches and functional recovery. Invest Ophthalmol Vis Sci 49, 772-780.

[193] McGeer PL, McGeer EG (2008) Glial reactions in Parkinson's disease. Mov Disord 23, 474-483.

194] Schwab C, McGeer PL (2008) Inflammatory aspects of Alzheimer disease and other neurodegenerative disorders. $J$ Alzheimers Dis 13, 359-369.

[195] Mogi M, Togari A, Ogawa M, Ikeguchi K, Shizuma N, Fan D, Nakano I, Nagatsu T (1998) Effects of repeated systemic administration of 1-methyl-4-phenyl-1,2,3,6tetrahydropyridine (MPTP) to mice on interleukin-1beta and nerve growth factor in the striatum. Neurosci Lett 250, 25-28.

[196] Przedborski S, Jackson-Lewis V (1998) Experimental developments in movement disorders: update on proposed free radical mechanisms. Curr Opin Neurol 11, 335-339.

[197] Tichauer J, Saud K, von Bernhardi R (2007) Modulation by astrocytes of microglial cell-mediated neuroinflammation: effect on the activation of microglial signaling pathways. Neuroimmunomodulation 14, 168-174.

[198] Koutsilieri E, Scheller C, Grunblatt E, Nara K, Li J, Riederer P (2002) Free radicals in Parkinson's disease. J Neurol 249(Suppl 2), II1-5.

[199] Schwaninger M, Neher M, Viegas E, Schneider A, Spranger M (1997) Stimulation of interleukin-6 secretion and gene transcription in primary astrocytes by adenosine. $\mathrm{J} \mathrm{Neu}$ rochem $\mathbf{6 9}, 1145-1150$

[200] Hasko G, Pacher P, Vizi ES, Illes P (2005) Adenosine receptor signaling in the brain immune system. Trends Pharmacol Sci 26, 511-516.

[201] Horrigan LA, Kelly JP, Connor TJ (2006) Immunomodulatory effects of caffeine: friend or foe? Pharmacol Ther 111, 877-892.

[202] Yu L, Huang Z, Mariani J, Wang Y, Moskowitz M, Chen JF (2004) Selective inactivation or reconstitution of adenosine A2A receptors in bone marrow cells reveals their significant contribution to the development of ischemic brain injury. Nat Med 10, 1081-1087.

[203] Shaftel SS, Griffin WS, O'Banion MK (2008) The role of interleukin-1 in neuroinflammation and Alzheimer disease: an evolving perspective. J Neuroinflammation $\mathbf{5}, 7$.

[204] Selkoe DJ (2002) Alzheimer's disease is a synaptic failure. Science 298, 789-791.

[205] Terry RD, Masliah E, Salmon DP, Butters N, DeTeresa R, Hill R, Hansen LA, Katzman R (1991) Physical basis of cognitive alterations in Alzheimer's disease: synapse loss is the major correlate of cognitive impairment. Ann Neurol 30, 572-580.

[206] Spires-Jones TL, Meyer-Luehmann M, Osetek JD, Jones PB, Stern EA, Bacskai BJ, Hyman BT (2007) Impaired spine 
stability underlies plaque-related spine loss in an Alzheimer's disease mouse model. Am J Pathol 171, 1304-1311.

[207] Dong H, Martin MV, Chambers S, Csernansky JG (2007) Spatial relationship between synapse loss and beta-amyloid deposition in Tg2576 mice. J Comp Neurol 500, 311-321.

[208] Rutten BP, Van der Kolk NM, Schafer S, van Zandvoort MA, Bayer TA, Steinbusch HW, Schmitz C (2005) Agerelated loss of synaptophysin immunoreactive presynaptic boutons within the hippocampus of APP751SL, PS1M146L, and APP751SL/PS1M146L transgenic mice. Am J Pathol 167, 161-173.

[209] Prescott IA, Dostrovsky JO, Moro E, Hodaie M, Lozano AM, Hutchison WD (2009) Levodopa enhances synaptic plasticity in the substantia nigra pars reticulata of Parkinson's disease patients. Brain 132, 309-318.

[210] Calabresi P, Maj R, Pisani A, Mercuri NB, Bernardi G (1992)
Long-term synaptic depression in the striatum: physiological and pharmacological characterization. J Neurosci 12, 42244233.

[211] Calabresi P, Galletti F, Saggese E, Ghiglieri V, Picconi B (2007) Neuronal networks and synaptic plasticity in Parkinson's disease: beyond motor deficits. Parkinsonism Relat Disord 13 Suppl 3, S259-262

[212] Calabresi P, Picconi B, Tozzi A, Di Filippo M (2007) Dopamine-mediated regulation of corticostriatal synaptic plasticity. Trends Neurosci 30, 211-219.

[213] Goldberg MS, Pisani A, Haburcak M, Vortherms TA, Kitada T, Costa C, Tong Y, Martella G, Tscherter A, Martins A, Bernardi G, Roth BL, Pothos EN, Calabresi P, Shen J (2005) Nigrostriatal dopaminergic deficits and hypokinesia caused by inactivation of the familial Parkinsonism-linked gene DJ1. Neuron 45, 489-496. 